\title{
The Impact of Head Trauma on Society
}

\author{
Leslie P. Ivan, President, Canadian Neurosurgical Society
}

Can. J. Neurol. Sci. 1984; 11:417-420

In this address I shall discuss head trauma from an angle which may be unusual for neuroscientists. Our preoccupations are diagnostic challenges and management problems, but that which we experience at the bedside is only a narrow segment of a continuum which started with trauma somewhere in a war, on the road, at home, on the football field, in the boxing ring, and in many other distinct locations. When our role is over, there are only three places where head trauma victims can be found; in cemeteries, where every year, 5,000 new graves are made to accommodate fatal head injuries in Canada; in chronic hospitals, which are already overloaded with victims of various insults to the brain, and, of course, within society, which accepts the fully recovered or tolerates the subtle and not so subtle consequences of so-called 'minor' head injuries.

To begin, I shall focus on trauma itself and will try to define the magnitude of the problem and match the response of society to it. The magnitude of a health problem, can be judged from the incidence, mortality, and morbidity figures and from the financial costs to society (Waller, 1980). A major epidemic is a disaster in continuity which keeps decimating the population and saps the financial resources of society. But, according to Brian Jennett: "Head injured patients are so common place that they often fail to attract the attention they deserve." (Jennett and Teasdale, 1981)

Let us examine the facts more closely. Reliable data are collected regularly and come from a number of sources. The National Head and Spinal Cord Injury Survey (Anderson and McLaurin, 1980), a supplement to the Journal of Neurosurgery, and the Central Nervous System Trauma Research Status Report (Odom, 1979) remain excellent documents which can be updated from the World Health Organization Vital Statistics. From these, and other published statistics (Canadian 1982; Causes 1977, 1980; Hospital 1978; World Almanac 1970-1983), it can be established that the annual incidence of serious head trauma is very high, and affects as many as 20,000 to 30,000 people in Canada. The variation of 100 to 700 per 100,000 population is age specific, and a tragic peak occurs between 15 and 19 years of age. This should be noted and imprinted on the conscience of all parents of the world.

About 100,000 people die in the United States every year because of accidents. Half of these deaths are related to road accidents; $70 \%$ of fatal injuries occur because of head trauma. In Canada, the situation is not much better, despite the fact that we passed the highest peak in 1973, when road fatalities alone claimed nearly 7,000 lives. In the 1970's sharing the distinction with West Germany, and surpassing the United States, WE were the world leaders in highway fatalities and WE had the highest percentage of accidental deaths in the world. There is overwhelming proof from excellent studies covering several geographic locations, that road accidents are the single most common cause of head injuries (51\%), surpassing the home, which nevertheless, maintains the distinction of being the second most dangerous place for the head.

Looking at morbidity, the picture remains equally distressing. Figures for the United States show that there were 9 million disabling injuries in 1981, resulting in 350,000 cases of permanent disability. We don't have reliable figures in Canada, but as a rough estimate, $10 \%$ would probably be realistic.

Translating the morbidity and mortality figures to dollars and cents, the cost of accidents has grown from 18.2 billion dollars in 1970 to 78.4 billion dollars in 1982 in the United States. Motor vehicle accidents account for nearly half of these expenses. Head injuries, therefore, in Canada, cost at least 4 billion dollars per year.

At a recent Trauma Conference in Calgary, Professor John Read stated, "One in twenty Canadian children born today will be killed or severely injured before reaching the age of 15 (Read, 1984). The majority of these injury events will occur in traffic." Just think about it for a minute. The world's population will be about 6 billion in the year $2000,2.5$ billion of which will be children under 14 years of age. If all countries on earth were as advanced as we are technologically, 1.25 million children would die in the year 2001 because of head injuries alone.

In this frightening shadow of an Orwellian forecast, my second concern in this address is to examine society's response to the vastness of the problem and ask:

1. Is it really true that accident is a natural phenomenon?

2. Do head injury patients fail to attract the attention they deserve?

3. Is it really tenable that in 15 years, accidents will continue decimating the children of this country?

Allow me to illustrate the "Vital Signs" of society or the "Coma Scale", if you wish, whereby the response of society can be assessed. Whether a society is alert or in coma may be gauged by testing cultural and organizational phenomena, checking what industry, government and the law do about a noxious reality, and testing how society propagates new knowledge, processes new information, and implements the needed change.

Let us look first at Canadian and American agencies concerned with trauma. These organizations which represent the medical profession, business, industry, government and citi- 
zen groups are listed in Table 1 . These are only about $40 \%$ of the agencies concerned internationally with trauma and head injuries.

Organized medicine should be proud of the leadership of the American College of Surgeons which has been a powerhouse of resources on how to establish and maintain effective structural and high professional standards in the management of trauma victims. The number of brochures, pamphlets and symposia, reflect the profound concern of the American College about this epidemic of civilized living which can be subdued by improving every phase of trauma management.

In Canada, I must confess, there has been a slow awakening, but within the past few years, from the Royal College to the Canadian Medical Association, the activity has been very impressive.

Time prevents me from checking the "Vital Signs" of society systematically and exhaustively. I shall, however, touch upon a few issues which I consider important because they reflect Canadian concern. These are: 1 . Head protection, 2. Injuries to children, 3. Alcohol and youth, 4. Seat-belt and restraint, 5. Trauma research funding.

\section{Head Protection}

Great events in history have hinged on head protection. It is no secret that Goliath had a helmet of brass upon his head and that his helmet had a rather substandard construction for David "smote the Philistine, the stone sunk into his forehead and he fell upon his face to the earth." The Romans and Greeks had excellent helmets. Alexander the Great (330 B.C.) had a fluted helmet which successfully deflected blows to his head, and saved his life in many battles. Obviously, a man ahead of his time, he decreed that in all campaigns, horse soldiers should wear helmets. The current trend is in agreement with him, as protective devices in transport, sport, and leisure activity are showing a resurgence today.

The excellent posters of the Ontario Easter Seal Society uses the best psychology to reinforce the use of sports helmets. The improvement of existing helmets is very important, as is shown by a study covering five years of football injuries in the United States (Schneider, 1982) In this study, 69 subdural haematomas with 28 deaths occurred because the helmets did not properly absorb the energy from severe impact. This prompted research to improve helmet design and reduce injury.

In our study, we found bicycle injuries the single most common cause of head injury in children (Ivan et al., 1983; Lapner and Ivan, 1981). We suggest the use of helmets for cyclists and bicycles that are CSA (Canadian Standards Association) approved. We hope that legislation will deal with these issues.

Concerning motorcycle helmets, in the United States, 35 states repealed mandatory motorcycle helmet legislation in May of 1976 (Watson et al., 1980). The result, an increase in head injuries and death, and a $200 \%$ increase in medical cost and disability (McSwain and Petrucelli, 1984).

This might be the time to reflect on boxing. The World Federation of Neurosurgeons and the Canadian Neurosurgical Society have been fighting this savage sport for a long time. Last year, our view was presented (by $\mathrm{Dr}$. J. Stratford) to the Canadian Medical Association. In a recent letter, I was informed that the Canadian Medical Association has made a resolution that boxing be banned in Canada, while the Ontario Medical Association, at its annual meeting, indicated that all boxing need not be banned (Rich, 1984). Dr. George Lundberg, in a recent editorial, stated that blows to the head should be made illegal, as have blows to the testes (Newsbriefs, 1984).

\section{Injuries to Children}

Injuries to children is a special issue because of the enormity of the mortality figures compared to other causes of death in childhood (Accidents, 1981). Interestingly, the most revealing figures come from the Cancer Journal for Clinicians (Silverberg, 1982), which clearly shows that accidents in the United States killed more children between 1 and 14 years of age, than cancer, congenital anomalies, heart disease, meningitis, cerebral palsy and cystic fibrosis, altogether. For children, the road is deadly, but for toddlers and infants, the home remains the commonest place of head trauma, and through the Canada Safety Council and the Canadian Institute of Child Health, we have convinced the government to modify safety standards for stairs, walkers and homes.

\section{Alcohol and Youth}

Drinking and driving is a serious problem in all age groups (Simpson, 1982; Zuska et al., 1983). The Canadian Automobile Association tells us that in 1981 , from the 641 persons killed in traffic accidents, 376 had been drinking. The Bulletin of the American College of Surgeons states, and I quote, "More than 2 million Americans died in wars since 1775" (Connaughton, 1983). Since approximately $50 \%$ of motor vehicle deaths are alcohol related, it becomes apparent that drinking and driving has killed more on the streets and highways than we have lost in all wars as a nation." Alcohol abuse and road trauma combined are the leading causes of death between 17 and 21 years of age. A recent study in the province of Ontario revealed that from 484 fatally injured drivers and paedestrians in one year, only $32 \%$ had neither alcohol nor drug in their blood samples (Warren and Simpson, 1980).

The Ontario Medical Association Committee on Accidental Injuries has made specific recommendations for strategies to decrease drinking and driving (Committe, 1984). This may ultimately result in provincial legislation. The Law Reform Commission of Canada has already forwarded a report to Parliament with specific recommendations about alcohol related issues (Report, 1983).

One of the best documents I had in my hands, revealing society's concern is the booklet Task Force of the Government of Ontario on Drinking and Driving (Discussion, 1983). It deals with the problem in depth, both nationally and internationally. At the request of a citizen's group, a Task Force was established by Premier W. Davis in the fall of 1982, in order to spur a new assault on the problem. The Task Force made several recommendations in this study which should surface soon in Parliamentary debate.

The Traffic Injury Research Foundation has an equally valuable document in which the emphasis is again on youth with specific reference to changing social behaviour and attitudes towards drinking and driving (Alcohol, 1983). This report also emphasizes the development of community based strategies. Examples of these are M.A.D.D. (Mothers Against Drunk Driving), S.A.D.D. (Students Against Drunk Driving). Many of these voices reach the media quite frequently, and some concern appear on such things as shopping bags issued by the Liquor Control Board of Ontario. In magazines, unfortunately, 
alcohol is a frequent object of beautiful advertisements. In the distinguished Canadian Geographic (Canadian, 1984), I found five excellent ads, promoting alcohol. The one which caught my eye was Seagrams, which says "When we say don't drink and drive we're not just talking about liquor. Twelve ounces of beer, a $51 / 2 \mathrm{oz}$. glass of wine and $1 \frac{1}{2} \mathrm{oz}$. of spirits - they all contain the same amount of alcohol. So they're all equally wrong to mix with driving, and for that matter, just as wrong to abuse at any time". Moral or immoral, conformist or not, it is good to know that at least one of the merchants of this lethal combination feels some societal pressure.

\section{Seatbelts and Restraining}

There has been a remarkable decrease in deaths and injuries since January 1st, 1976, when seatbelts became mandatory in Ontario. In 1975, the year before seatbelt legislation, 1314 drivers and passengers were killed in motor vehicle accidents in Ontario. In 1982, Canadian Road Fatality Statistics show that the number had dropped to 783 , a drop of $40 \%$; the lowest number of deaths and injuries since 1965 . Unfortunately, seatbelt laws in many countries are not enforced, or if they are, the compliance may be low. A recent blitz in Ottawa showed only $74 \%$ adult and $60 \%$ child restraint compliance which improved by $10 \%$ after a second blitz (Surveys, 1984). Child restraint legislation is now in effect in Ontario, Quebec, Manitoba, Nova Scotia, Newfoundland, Saskatchewan and 41 states of the United States. It remains, however, a matter of education and legislation to protect little citizens who cannot make the decision to protect themselves.

Some researchers believe that a passive restraint system will improve the problem and industrial research remains very active in this field. The U.S. government has recently legislated that air bags and automatic seat belts will be phased into new cars by the manufacturers.

\section{Trauma Research}

Finally, I would like to touch upon trauma research. In spite of the improvement of mortality with agressive treatment of severe head injuries, we seem to have reached a plateau where further improvement remains questionable. Maybe it is true, that a scrambled brain cannot be unscrambled; but, there is plenty of room for research. (Ghent, 1981)

Certain therapeutic vacuums exist which may effect society and man in a rather insidious manner. Probably the two most important areas which deserve more research are from the moment of the 'accident' to the earliest possible management of coma, and the subtle consequences of head injuries. As an example; a 15 year old boy suffered a slight head injury while under the influence of alcohol, when he fell backwards and struck his head on the floor. He had a Glasgow coma scale of 12 at admission and left the hospital in less then a week. The CT scan showed, to our astonishment, a dozen small contre-coup haemorrhages in the frontal and temporal areas. He went back to school, but dropped out before graduating, and now works as a painter's helper.

I recently saw him again when he was painting the walls of the hospital where he was treated. He is jolly, uninhibited, calls himself a paintologist and is reintegrated to productive life; but is he really? Can we measure his loss? What else could he have painted? Why did he drop out of school?

Nobody can answer these questions for we don't know the value of lost neurons, and how can we know, when such a small amount of money is spent on head injury research. The figures are embarrassing for only one percent or less of the grant dollars support head injury research. People who suffer from incurable diseases have my deepest sympathy and l am happy for the millions of dollars governments will spend to attempt to solve their problems, but I also have healthy children and three of them are teenage drivers. From the depth of my heart I am crying for all teenagers of Canada and the world, that we may find the wisdom and the money to stop their slaughter on the roads.

Prevention should be the solution, but prevention comes from education and education is the transfer of knowledge. Knowledge can be based only on experience and research, and education and research together are the key issues to the solution of the problem of head trauma.

Neuroscientists should be the champions of this cause, for they know best that the greatest treasure of evolution is the human brain. There should be a new line of evolution in society, not the fittest, but the wisest. An evolution which brings deeper maturity and wisdom to human behaviour, a changed attitude which will protect man from self-destruction. Head injury is not a natural phenomenon. It comes from a hostile environment which is man made and it should be controlled by man.

According to my analysis, the vital signs of our society are quite stable. We are making progress and the scores are quite high on the responsiveness scale. The two weak areas, research and education, are strongly dependent on government support and as we know, it takes a long time before the fixed pupils of some government agencies start responding to light.

\section{ACKNOWLEDGEMENTS}

I am indebted to my wife, Maureen, who helped research this problem and put the material into perspective. Dr. W. R. Ghent from Kingston, Mr. Rotenburg from the Ontario Medical Association, Dr. Da Sylva from the Canadian Medical Association and all the organizations listed in Table 1 generously provided valuable information and assistance. 
Table 1: Partial list of North American agencies and organizations concerned with trauma

\begin{tabular}{l}
\hline Canadian Institute of Child \\
Easter Seal Society of \\
Ontario ('Head First') \\
Head Injury Association of
\end{tabular}

Canada (Parents)

Canada Safety Council

Traffic Injury Research

Foundation

Biokinetics and Associates Ltd.

Canadian Medical Association

Ontario Medical Association Consumer Association of
Canada

\section{American Association of Automotive Medicine}

Health and Welfare Canada

Transport Canada

\section{Consumer and Corporate Affairs}

Statistics Canada - Health Division

Ministry of Transportation and Communications

Canadian Trauma Foundation
17 York Street

Suite 202

Ottawa, Ontario

K1N 5S7

PO Box 663

Station " $K$ "

Toronto, Ontario

M4P 2HI

PO Box 8464

Dundas, Ontario L9H 6M2

1765 St. Laurent Blvd.

Ottawa, Ontario

K1G 3V4

171 Nepean Street

Ottawa, Ontario

K2P 0B4

1481 Cyrville Road

Ottawa, Ontario

K1B 3L 7

Committee on Trauma

1867 Alta Vista Drive

Ottawa, Ontario

K1G 0G8

Committee on Accidental Injuries 240 St. George Street

Toronto, Ontario

M5R 2P4

251 Laurier Ave. W.

Suite 703

Ottawa, Ontario

K1P $5 J 6$

40 Second Avenue

Arlington Heights, Illinois

USA 60005

General Inquiries,

(613) 996-4950

Road Safety

Place de Ville

Ottawa, Ontario

K1A 0N5

General Inquiries

Inquiries

(613) 995-9544

1201 Wilson Avenue

Downsview, Ontario

M3M $1 J 8$

Address enquiries to the attention of: Dr. W.R. Ghent

C.M.A. House

1867 Alta Vista Drive

Ottawa, Ontario

K1G 0G8
(613) $997-2938$

\section{REFERENCES:}

Accidents in Childhood (1981) Office of Health Economics. London, England.

Alcohol and Roád Accidents - future strategies and priorities (1983). Proceedings of Workshop by the Traffic Injury Research Foundation and Alberta Alcoholism and Drug Abuse Commission.

Anderson DW, McLaurin RL (1980) The National Head and Spinal Cord Injury Survey. J Neurosurg (suppl).

Canadian Geographic (1984) 104: 89

Canadian Motor Vehicle Traffic Accident Statistics (1982) Transport Canada.

Causes of Accidents (1977) Statistics Canada, Health Division 14-19.

Causes of Death (1980) Statistics Canada. 178-195.

Committee on accidental injuries (1984) OMA Reports to Council, Toronto. 62-66.

Connaughton M (1983) Treating the Trauma Victim. ACS Bulletin 68 , Chicago.

Discussion Paper of the Task Force on Drinking and Driving (1983) Government of Ontario, Toronto.

Ghent WR (1981) Salus populi supremis lex: a medical perspective. Proceedings of International Symposium on Occupant Restraint. American Association of Automative Medicine and Ontario Department of Transport.

Hospital Morbidity (1978) Statistics Canada. 134-143.

Ivan LP, Choo SH, Ventureyra ECG (1983) Head injuries in childhood: a 2-year survey. Can Med Assoc J 128: 281-284.

Jennett B, Teasdale G (1981) Management of Head Injuries. Philadelphia, Davis Co, $\mathrm{V}$.

Lapner M, Ivan LP (1981) Bicycle injuries among children. Can Med Assoc J 125:132.

McSwain NE, Petrucelli E (1984) Medical consequences of motorcycle helmet nonusage. J Trauma 24: 233-236.

Newsbriefs (1984) Can Med Assoc J 131: 60.

Odom GL (1979) Central Nervous System Trauma Research Status Report. National Institutes of Health, US Public Health Service.

Read JH (1984) The injury event and the injury problem. Proceedings of Injury-Trauma Conference, University of Calgary.

Report on Investigative Tests. Alcohol, drugs and driving offenses (1983) Law Reform Commission of Canada, Ottawa.

Rich, Pat (1983) All boxing need not be banned, group indicates. The Medical Post, June 26, 6.

Schneider RC (1982) The incidence of head injuries: the potential for protection. Proceedings of Head Protection. The State of the Art. University of Birmingham, England. 5-14.

Silverberg BS (1982) Cancer Statistics CA 32: 30.

Simpson HM, Mayhew DR, Warren RA (1982) Epidemiology of road accidents involving young adults: alcohol, drugs and other factors. Drug Alcohol Depend 10: 35-63.

To Drive? or Not to Drive? The Medical Answer (1981) CMA, Ottawa.

The World Almanac and Book of Facts (1970-1983) New York, Newspaper Ent

Waller JA (1980) Injury as a public health problem. In Last JM (Ed), Maxcy-Rosenau Public Health and Preventative Medicine, 11th ed., East Norwalk CT, ACC. 1549-1592.

Warren R, Simpson HM (1980) Drug involvement in traffic fatalities in the province of Ontario. Proceedings of American Association of Automotive Medicine. 16-25.

Watson GS, Zador PL, Wilks MA (1980) The repeal of helmet use laws and increased motorcyclist mortality in the United States, 1975-1978. Am J Public Health 70: 579-584.

Zuska JJ, Orange CA, Trunkey DD, Hering AC (1983) Alcohol abuse, road trauma, and the role of medical professionals. ACS Bulletin 68: $22-24$.

Survey finds $80 \%$ of area motorists buckling up (1984), Ottawa Citizen, June 27, 1 . 